\title{
Special Education Practice at Elementary Level in European Union Countries and Turkey
}

\author{
Pelin Pistav Akmese, ${ }^{1, *}$, Nilay Kayhan ${ }^{2}$ \\ ${ }^{1}$ Faculty of Education, Department of Special Education, Ege University, Turkey \\ ${ }^{2}$ Faculty of Education, Department of Special Education, Hasan Kalyoncu University, Turkey
}

Copyright $\mathrm{O} 2016$ by authors, all rights reserved. Authors agree that this article remains permanently open access under the terms of the Creative Commons Attribution License 4.0 International License

\begin{abstract}
An individual's development and education process that starts in the family environment continues in the educational institutions. The primary school education period, which is the basis for the children's future achievements, should include regulations based on the equality of opportunity and access to education. The aim of this study is to examine in a comparative manner the school starting age of students with special requirements in Turkey and European Union countries and educational model applied, supports provided to students and classroom teachers, and the variables relating to other personnel. This study is a descriptive study aiming at determining the existing circumstances. In most of the EU countries integration, inclusion and separate training model for children with special educational requirements are applied together and as a whole in the primary school age. In addition, in the countries in which the integration and inclusion implementations are applied densely, families are provided with family training, health, financial and transportation supports together with support to academic skills for school teachers, and guidance and training service for families in terms of behavioral management.
\end{abstract}

Keywords Elementary Education, Special Education, Elementary School, Elementary Institutions

\section{Introduction}

An individual's development and education process that starts in the family environment continues in the educational institutions. The primary school education period, which is the basis for the children's future achievements, should include regulations based on the equality of opportunity and access to education. The quality of training provided in this age in which an individual is getting accustomed to real life in terms of both social and emotional aspects differs for educational personnel and students. It is an obligation according to the law to support the development of the children with different developmental properties together with their peers; implementations may vary from country to country according to their educational policies [1]. Special education is an educational practice for the children and teens who were diagnosed in one or more disability field and have special educational needs. In the Regulation on the Special Education Services in Turkey, the individual who needs special education is defined as the individual who shows statistically significant difference for various reasons than the level expected from his/her peers in terms of personal, developmental characteristics, education performance. It has been seen that the educational practices conducted for the children with special educational needs with their peers between the compulsory education age range in both Turkey and European Union member countries. The medical and educational assessments have been conducted regarding the disability type and level in the diagnosis process of the individuals with special educational needs. When deciding the program in which the child will be included, the diagnosis criteria in the medical assessments and educational performance resulted from the educational assessment have been taken into account [2-4]. It has been accepted in Turkey that the individuals who were diagnosed with one or more of attention deficit and hyperactivity disorder, motor speech disorder, mental and behaviour disorder, visual disability, auditory disability, physical disability, autism spectrum disorder, special learning disability, cerebral palsy, chronic diseases, mental deficiency and giftedness need special education and supportive educational services $[2,14]$.

Special education regards the individuals who have developmental differences compared to their peers. These individuals need to be supported to be able to perform their roles in the society which they live in, to live independently and to become self-sufficient. For this purpose, the children with special educational needs should receive an education in accordance with their educational needs, competence, interest and talent using the appropriate curriculum, special methods, personnel, and tools [2,20,21].

In this study, the "individual with special educational 
needs" definition has been used as stated in the national and international literature. Ministry of National Education Regulation on the Special Education Services (2015) was used for the national definition while Diagnostic and Statistical Manual of Mental Disorders (DSM-5), one of American Psychiatric Association publications, was used for the diagnoses regarding the child with the special educational needs in the international definition. According to DSM-V and Diagnoses for Children, the children who have one or more of the diagnoses above have been accepted as the children with special educational needs/children with disabilities.

All educational arrangements being carried out under the certain program or not do have an influence on lives of individuals [5]. These arrangements vary depending on the development levels of countries and their economic, cultural, social and political status. Since the level at which individual requirements are met may be affected by the development level of society, quality of educational environments which take into account the individual requirements should be assessed according to the principle of equality of opportunity [6].

In our country, for the school year 2012-2013, each child who turns his/her $66^{\text {th }}$ month (born on or before 31 March 2007) as of 30 September 2012 shall start primary school. Registrations for primary school are carried out automatically by use of the address-based database through e-school system. This arrangement which was entered into force as an alternative to the 8-year continuing education applied in the previous period is stated as $4+4+4$. Ministry officials who criticize that the individual differences of the students were ignored and the age groups were not taken into account in 8-year continuing education state that 12-year continuing education is built on two main purposes. The first of these purposes is to increase the average education period of the individual, and the other is to construct the education system to be able to direct the individuals according to their needs, interests, and abilities. When the compulsory education period regulations in 2012 are examined, it draws attention that the children who are over 36 months old can start preschool education [6-8].

The regulations regarding the compulsory age of starting preschool and basic education concern both the children with normal development and the children with special educational needs, who shows statistically significant developmental differences from their peers. It has been stated that the regulations regarding the age of starting school are parallel to two laws which are accepted as the fundamental laws of the national education system; National Education Basic Law no. 1739 and Primary Education Law no. $222[6,8]$. The regulations and amendments regarding the school starting age of the children with normal development and the children with special educational needs are stated in the Ministry of National Education Regulation on Preschool and Primary Education Institutions which was published in the Official Gazette dated July 26, 2014, and numbered
29072 as follows [8]. It has been stated in Part 3 that the children who completed their 36 months and hasn't completed 66 months by the end of the September of the enrollment year are enrolled in nursery and application classes in the enrollment process in preschool institutions regarding School Assessment, Enrollment, Admission, and Attendance. Besides, the children who turn their $48^{\text {th }}$ month and haven't completed their $66^{\text {th }}$ month as of the end of the September of the enrollment year shall be enrolled in nursery schools. However, in the which don't have enough children to form a group, the children between their $36-47^{\text {th }}$ months can also be enrolled in nursery school Another important regulation which has been implemented since it was published in the Official Gazette dated October 23, 2014, and numbered 29154 is that children whose enrollments were postponed upon the written request of the parents or medical report shall be enrolled in preschool education institutions primarily. On the other hand, the most important part of the regulations regarding the compulsory education starting age of the children with special educational needs is that the regulations regarding the early childhood and preschool period are included in these regulations $[6,8]$. The importance of special education support services and the necessity of the early education of all age group have been argued in the regulations. Early education programs that involve the individuals between their $0-36^{\text {th }}$ months have been applied in special education early childhood education units that are opened by directorates of national education in special education centers in accordance with the proposal of special education services board. The regulations which were published in Official Gazette dated June 25, 2015, and numbered 29397 are concerned with the preschool period education of the children with special educational needs and their transition to primary school. When the age of starting to preschool education and the attendance period are examined, the children who turn their $36-71^{\text {st }}$ months shall be directed to the preschool education institutions through full-time inclusive education in accordance with the reports of Special Education Assessment Board which was formed in Counseling and Research Centers. The classroom size is formed that there shall be one child in a class of 10, and two children in a class of 20 . Moreover, the children who cannot continue the education through inclusive education and who have a high level of disability, the children with more than one disability shall be enrolled in the special education classes as the capacity of the institution is enough and a special education teacher is employed according to the report of Special Education Assessment Board. The child who needs special education/diagnosed with a disability is defined as the individual who shows statistically significant difference for various reasons than the level expected from his/her peers in terms of personal, developmental characteristics, education performance $[6,18]$.

The $6^{\text {th }}$ Article [14] of the same regulation states the regulation regarding the enrollment in the primary school. It has been stated in the Paragraph a of Article 6 that while the 
children who completed their $66^{\text {th }}$ month by the end of the September of the enrollment year can enroll in the school, the children who are between their $60-66^{\text {th }}$ months and whose developments are found to be sufficient to start school can be enrolled in the first grade with the written request of the parents. The following responsibility given in the same article to the principals of the schools draws attention. According to the Paragraph $\mathrm{b}$ of Article 6, for the children who has the right to enroll in the school because of their age, the school principals can direct the children who are in their $66,67,68^{\text {th }}$ months with the petition of their parents and the children who are in their $69,70,71^{\text {st }}$ months with the medical report that states they are not ready to start primary school to preschool education or can delay their enrollment for one year. The children who are in the compulsory primary school period and haven't enrolled in the school for any reasons are enrolled in the first grade.

Primary school session is a process in which children's physical, emotional, social and mental developments are supported in an educational environment which is suitable for the children's individual properties and development levels. Since basic habits and mental skills quickly develop and take a shape in preschool and primary school age, integration programs that provide an opportunity to each individual to receive training together with his/her peers and that are based on individual differences and equality of opportunity should be promoted and supported. Children who attended integration implementations in the preschool and primary school age showing more educational attainment in the future require arrangements for individual requirements to be taken in terms of health and accomplishments of next generations [1,9]. On the other hand, the support provided to children and their families is a determining and essential item which bears the characteristics of primary education. Examination of cooperation-based services provided would have an influence on the determination of quality benchmarks for primary education as well as enabling taking root and improvement of models based on the principle of equality of opportunity $[10,11]$. The quality of education provided in preschool and primary school age forms the basis of social skills and academic accomplishments of children; which reveals the importance of support provided to children with several incapabilities in terms of their social, mental, emotional and language development like their peers [10-13]. As it is in the rest of the world, the preschool education which is the preparation period for the primary school and the following years is accepted as an important process in our country. So, the preschool education is compulsory for the children with special educational needs and who are between their $37-66^{\text {th }}$ months. However, this can be extended to 78 months with the written consent of the parents and report of the Special Education Assessment Board. The children who are enrolled through enrollment system (e-school) and whose attendance period for preschool is extended are accepted into the appropriate education institutions with the formal application of the parents and province/district special education services board's decision. It is of first priority for the children with special educational needs to be educated in the same way with their peers both in preschool and primary school periods. When the regulations in education regarding the age of the children with special educational needs are examined, it can be said that special education nursery for the children between their $37-66^{\text {th }}$ months, and special education nursery classes within the body of schools and institutions for the children between their $48-66^{\text {th }}$ months can be opened. Inclusive education applications are principal applications for the individuals who are in primary school and secondary school level. As Turkey, the most important variable of the special education services is to plan an education regarding the needs of the students and to provide support services to the teacher. Regardless of the age range, the individual progress of the student is based on his/her having a qualified support service. These opportunities provided to the students also concern the teachers and their families and determines the quality of the special education applications.

Children with special educational requirements and showing different development process in comparison with their peers who receive education and training together with other students with normal development process have a chance to learn how to assist each other by being aware of their strengths and weaknesses [15]. Since the quality of support services are affected by the level of support provided to personnel in charge and families, and other implementations in addition to individual properties of students, the aim of this study is to assess existing regulations and arrangements in effect in our country and those in European Union countries used for students with special requirements who receive educational services at primary school level [14].

\section{Materials and Methods}

The purpose of this study is to compare and analyze the elementary institutions that the students with special needs attend, the education model being implemented, education starting age, personnel number of the institutions and support services provided to the family. The study is a descriptive and aims to identify and define the present conditions. The data used in this study about the variables of EU countries and Turkey were obtained from Agencies of the European Union, European Agency for Development in Special Needs Education, Eurydice-Network on Education Systems and Policies in Europe, Eurybase-Descriptions of National Systems and Policies [16-21]. The students who benefit from special educational services receive their education in different educational models. These educational models are stated as inclusive (fully inclusive), mainstreaming and separate. One of these models, inclusive, also known as fully inclusive in some countries because of its full participation characteristic is a model which is recognized as integration 
in the literature. Another model in which the children with special educational needs are educated with their peers who show normal development is mainstreaming. In mainstreaming and inclusive models, educational regulations are made in the general education schools for the children with special educational needs $[2,14,15,27]$.

This study examines how the children with special educational needs receive education in different countries when they start compulsory education and what kind of supportive services are provided for them. The national literatures of the countries for the special education have been examined and it has been determined that with which diagnoses the children are expected as the individuals with special educational needs. The individuals with special educational needs are defined as the individuals who were diagnosed with one or more of Autism Spectrum Disorder, Disruptive Mood Dysregulation Disorder, Eating Disorder, Intellectual Disability, Internet Gaming Disorder, Major Depressive Disorder, Mild Neurocognitive Disorder, Obsessive-Compulsive and Related Disorders, Specific Learning Disorder, Social Communication Disorder, Somatic Symptom Disorder, Substance-Related and Addictive Disorders, Hearing Disability, Blind Disability [2-4,14].

The findings were retrieved by analyzing the countries' National Educational System Descriptions and the results were organized and interpreted with the use of tables. At first, the data were collected according to tothe reports the countries published in 2012-2013 academic year, the data updated on May 19, 2016, were reached by examining the every report published by the countries in accordance with the independent variables of the study. The information about Turkey and EU member countries have been gathered from the online reports on the web addresses European Agency for Development in Special Needs Education, Eurydice-Network on Education Systems and Policies in Europe Special Needs Education Within the Education Systems [17-20]. In the coding process, the two researchers examined these reports and the information on which they reached an agreement about how the special educational services were conducted have been excepted as data. The data are limited to the reports the researchers reached and the information on which they reached an agreement.

\section{Elementary school education system and special education in Turkey}

The eight-year compulsory education system has been in force since 1997 in Turkey. Educational services that had been carried out under the responsibility of two different bodies, general directorate of preschool education and general directorate of primary school, until 2012 was assembled under the same roof of General Directorate of Basic Education in 2012. In our country, the age at which children compulsorily start school is 5 years and 6 months and it is essential that individuals with special requirements attend both preschool and primary school education together with their peers. Arrangements and measures to be taken for students with special requirements are the responsibility of the General Directorate of Special Education and Guidance Services of the Ministry of National Education [6,14].

\subsection{Tables}

2.1.1. Elementary institutions, educational model and education enrolment age of students with special needs in Turkey and EU countries

The findings regarding the elementary education institutions, educational model and education enrolment age of students with special needs in Turkey and EU countries are presented in Table 1. As shown in Table-1, the compulsory age at which children shall start primary school in European Union members states [19] and in Turkey is between 5 and 7 . In some countries, this age interval may be delayed for one year for students with special requirements such as Sweden, Portugal, and Poland. On the other hand, in Southern Cyprus, Holland, Italy, Luxemburg and Greece these children start receiving education in early stages together with their peers after relevant diagnosis. The educational system adopted by Turkey and EU member states for students with special requirements for the primary school age is the collective education-based inclusion and integration model. Individual differences and type/degree of handicap are taken into consideration for those with special requirements who are attending appropriate schools according to relevant educational model under the countries' educational policies. The information regarding how the inclusive educational model and other educational models are applied to the children with special educational needs was gathered from EC (European Commission), Special Needs Education within the Education Systems, Online available at (http://www.european-agency.org/country-infor mation), Special Needs Education Within the Education Systems section by entering the name of the country subject to the examination [20]. Inclusive educational model and supporting educational services are all rendered under general educational environments in Austria and Italy while in Turkey and many of the EU countries (such as Belgium, Czech Republic, France, Ireland, Spain, Iceland, Malta, Hungary, Poland, Portugal, and Slovenia) inclusion classes are provided at special classrooms in general schools or at special schools. When the last compulsory education period regulations of the countries are examined, it can be found that Luxembourg is the country with the earliest age of starting school and the starting age is 4 . Mainstreaming is the educational model in which the children with special educational needs are educated in the same environment with their peers and in which the teacher and the student receive supportive services $[2,15]$. Separate is a practice in which the children with special educational needs receive special education in separate special classes or different educational environments than their peers [18]. In the country, the children continue preschool for two years after the age of 4 , and the period is followed by observation and evaluation of the transition plans and the support services Age of 6, instead of the age of 5, started to be applied as the compulsory 
education age in Poland as of 2013.

\subsubsection{The personnel in elementary school institutions where students with special needs attend}

The information regarding the personnel to provide service to students with special needs in Turkey and EU member countries is presented in Table-2 $[14,18,20]$.

In Table-2 information on personnel in charge of education and training of students with special requirements who are attending to primary schools. Personnel working at primary schools in Turkey and those of European Union member states share a similarity in respect of training field while there are differences between them in terms of another field, in particular for speaking therapists, family care experts, physiotherapists, social work experts $[14,18,19]$. In primary schools of Turkey the main responsibility is of student advisors, psychological advisors, classroom teachers, special training teachers while in many European Union member states (such as Austria, Belgium, Cyprus, Czech Republic, Denmark, Finland, Germany, Hungary, Portugal, Poland, Malta, and Luxemburg) relevant teams are composed of experts higher in number. In many European Union member states (Czech Republic, France, Hungary, Slovenia, Finland, Lithuania, Holland, Spain, Sweden) family counselors, health experts, special pedagogists, physiotherapists, language-speaking therapists, sign language experts, aesthetic arts experts, information technology experts, sports and music experts meet students with special requirements and their parents on certain days of a given week. Nevertheless, for the inclusive education model adopted by Turkey and EU states share a similarity in terms of cooperation with special training teachers, classroom teachers, student counselors and psychological experts $[6,7,14,18,19]$.

\subsubsection{The information about the support provided to families with children who need special education in Turkey and EU countries is presented in Table 3}

As shown in Table- 3 it should be noted that students with special requirements and their families benefit more from counseling and training services rendered. In most of the EU member states [17-21] (Cyprus, Czech Republic, Denmark, Finland, France, Germany, Greece, Hungary, Luxemburg, and Malta) it is a priority that migrant families and minorities and their children are enabled to get use of social benefits and bilingual children at their childhood and primary school age are considered individuals with special requirements [14,17-20]. For these children at this age who receive language support, team studies are preferred in health and training environments concerning their special requirements. Regarding the primary school age, it should be noted that both in Turkey and EU member states educational policies are based on taking measures necessary to enable these children to benefit from equal opportunities like their peers with the understanding that health, education, and counseling services should form an entire system [6,7,14-20].

Table 1. Elementary education institutions, educational model and education enrollment age of students with special needs in Turkey and EU [14, 17-23].

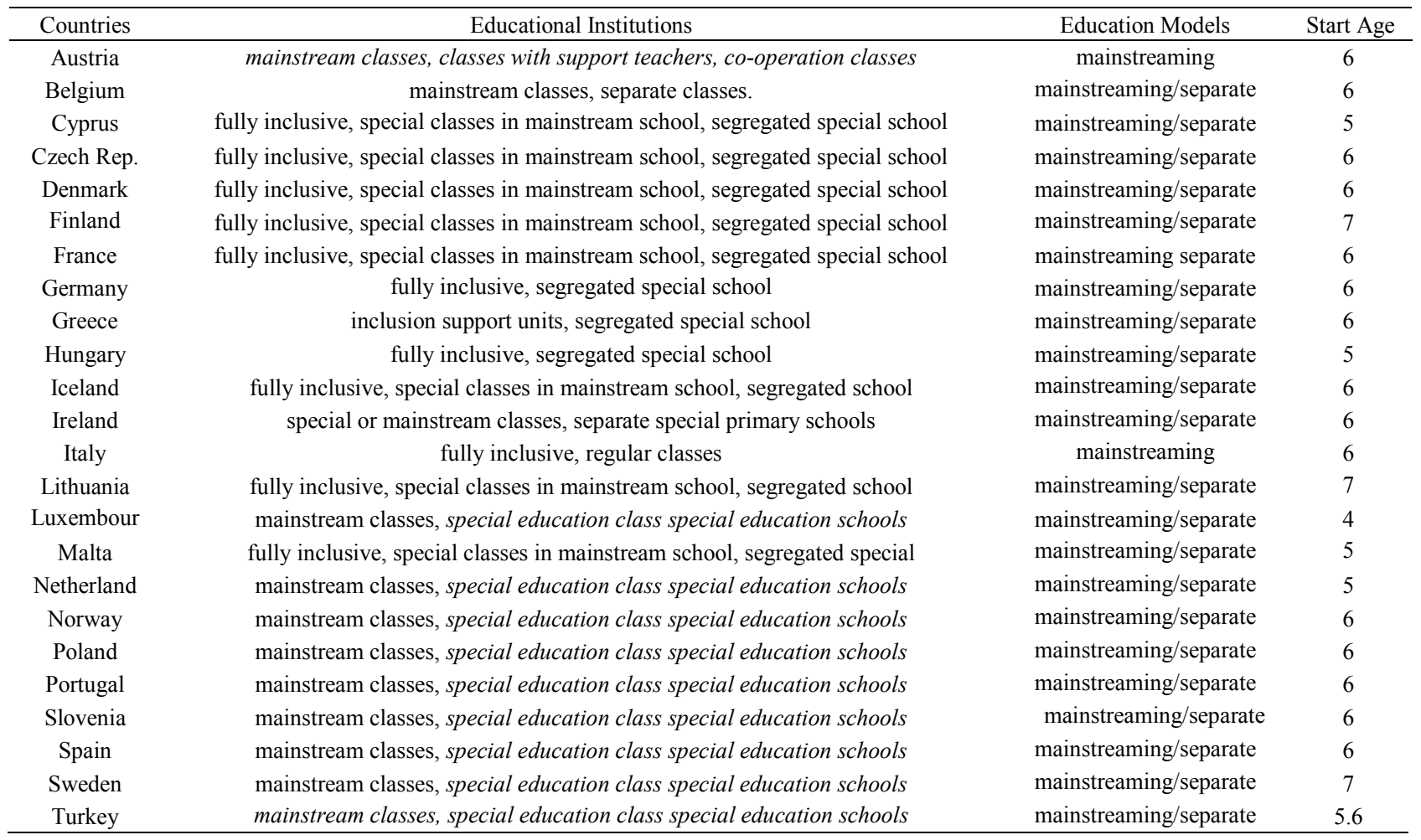


Table 2. The personnel working in elementary school education institutions in Turkey and EU countries [14, 17-22]

\begin{tabular}{|c|c|c|c|c|c|c|c|c|c|c|c|}
\hline \multirow[b]{2}{*}{ Countries } & \multicolumn{11}{|c|}{ Personnel } \\
\hline & $\begin{array}{r}\text { Family } \\
\text { Cares }\end{array}$ & $\begin{array}{r}\text { Health } \\
\text { Staff } \\
\end{array}$ & $\begin{array}{c}\text { Other } \\
\text { Specialists }\end{array}$ & Physiotherapist & $\begin{array}{c}\text { Special } \\
\text { Edc.Teac }\end{array}$ & $\begin{array}{c}\text { Psycho } \\
\text { logist }\end{array}$ & $\begin{array}{l}\text { Language } \\
\text { Specialist }\end{array}$ & $\begin{array}{c}\text { Social } \\
\text { Workers }\end{array}$ & $\begin{array}{l}\text { Elemantary } \\
\text { teacher }\end{array}$ & $\begin{array}{l}\text { Specialists } \\
\text { counsellor } \\
\text { (audiology) }\end{array}$ & $\begin{array}{c}\text { Teacher } \\
\text { Assistant }\end{array}$ \\
\hline Austria & & $\sqrt{ }$ & $\sqrt{ }$ & $\sqrt{ }$ & $\sqrt{ }$ & $\sqrt{ }$ & $\sqrt{ }$ & $\sqrt{ }$ & $\sqrt{ }$ & $\sqrt{ }$ & $\sqrt{ }$ \\
\hline Belgium & $\sqrt{ }$ & $\sqrt{ }$ & $\sqrt{ }$ & $\sqrt{ }$ & $\sqrt{ }$ & $\sqrt{ }$ & $\sqrt{ }$ & $\sqrt{ }$ & $\sqrt{ }$ & $\sqrt{ }$ & $\sqrt{ }$ \\
\hline Cyprus & & $\sqrt{ }$ & $\sqrt{ }$ & $\sqrt{ }$ & $\sqrt{ }$ & $\sqrt{ }$ & $\sqrt{ }$ & $\sqrt{ }$ & $\sqrt{ }$ & $\sqrt{ }$ & $\sqrt{ }$ \\
\hline Czech Rep & $\sqrt{ }$ & $\sqrt{ }$ & $\sqrt{ }$ & & $\sqrt{ }$ & $\sqrt{ }$ & $\sqrt{ }$ & $\sqrt{ }$ & $\sqrt{ }$ & $\sqrt{ }$ & $\sqrt{ }$ \\
\hline Denmark & & $\sqrt{ }$ & $\sqrt{ }$ & $\sqrt{ }$ & $\sqrt{ }$ & $\sqrt{ }$ & $\sqrt{ }$ & & $\sqrt{ }$ & $\sqrt{ }$ & $\sqrt{ }$ \\
\hline Finland & $\sqrt{ }$ & $\sqrt{ }$ & $\sqrt{ }$ & $\sqrt{ }$ & $\sqrt{ }$ & $\sqrt{ }$ & $\sqrt{ }$ & $\sqrt{ }$ & $\sqrt{ }$ & $\sqrt{ }$ & $\sqrt{ }$ \\
\hline France & $\sqrt{ }$ & $\sqrt{ }$ & & & $\sqrt{ }$ & $\sqrt{ }$ & $\sqrt{ }$ & $\sqrt{ }$ & $\sqrt{ }$ & $\sqrt{ }$ & $\sqrt{ }$ \\
\hline Germany & & $\sqrt{ }$ & $\sqrt{ }$ & $\sqrt{ }$ & $\sqrt{ }$ & $\sqrt{ }$ & $\sqrt{ }$ & $\sqrt{ }$ & $\sqrt{ }$ & $\sqrt{ }$ & $\sqrt{ }$ \\
\hline Greece & $\sqrt{ }$ & $\sqrt{ }$ & $\sqrt{ }$ & $\sqrt{ }$ & $\sqrt{ }$ & $\sqrt{ }$ & $\sqrt{ }$ & $\sqrt{ }$ & $\sqrt{ }$ & $\sqrt{ }$ & $\sqrt{ }$ \\
\hline Hungary & $\sqrt{ }$ & $\sqrt{ }$ & $\sqrt{ }$ & $\sqrt{ }$ & $\sqrt{ }$ & $\sqrt{ }$ & $\sqrt{ }$ & $\sqrt{ }$ & $\sqrt{ }$ & $\sqrt{ }$ & $\sqrt{ }$ \\
\hline Iceland & & $\sqrt{ }$ & $\sqrt{ }$ & $\sqrt{ }$ & $\sqrt{ }$ & $\sqrt{ }$ & $\sqrt{ }$ & & $\sqrt{ }$ & $\sqrt{ }$ & $\sqrt{ }$ \\
\hline Ireland & $\sqrt{ }$ & $\sqrt{ }$ & $\sqrt{ }$ & & $\sqrt{ }$ & $\sqrt{ }$ & $\sqrt{ }$ & $\sqrt{ }$ & $\sqrt{ }$ & $\sqrt{ }$ & $\sqrt{ }$ \\
\hline Italy & & $\sqrt{ }$ & & $\sqrt{ }$ & $\sqrt{ }$ & $\sqrt{ }$ & $\sqrt{ }$ & $\sqrt{ }$ & $\sqrt{ }$ & & $\sqrt{ }$ \\
\hline Lithuania & & & $\sqrt{ }$ & $\sqrt{ }$ & $\sqrt{ }$ & $\sqrt{ }$ & $\sqrt{ }$ & $\sqrt{ }$ & $\sqrt{ }$ & $\sqrt{ }$ & $\sqrt{ }$ \\
\hline Luxembourg & & $\sqrt{ }$ & $\sqrt{ }$ & $\sqrt{ }$ & $\sqrt{ }$ & $\sqrt{ }$ & $\sqrt{ }$ & $\sqrt{ }$ & $\sqrt{ }$ & $\sqrt{ }$ & $\sqrt{ }$ \\
\hline Malta & & $\sqrt{ }$ & $\sqrt{ }$ & & $\sqrt{ }$ & $\sqrt{ }$ & $\sqrt{ }$ & $\sqrt{ }$ & $\sqrt{ }$ & $\sqrt{ }$ & $\sqrt{ }$ \\
\hline Netherland & & & $\sqrt{ }$ & $\sqrt{ }$ & $\sqrt{ }$ & $\sqrt{ }$ & $\sqrt{ }$ & $\sqrt{ }$ & $\sqrt{ }$ & $\sqrt{ }$ & $\sqrt{ }$ \\
\hline Norway & & & $\sqrt{ }$ & & $\sqrt{ }$ & $\sqrt{ }$ & $\sqrt{ }$ & & $\sqrt{ }$ & $\sqrt{ }$ & \\
\hline Poland & $\sqrt{ }$ & & & & $\sqrt{ }$ & $\sqrt{ }$ & $\sqrt{ }$ & & $\sqrt{ }$ & $\sqrt{ }$ & $\sqrt{ }$ \\
\hline Portugal & $\sqrt{ }$ & & & & $\sqrt{ }$ & $\sqrt{ }$ & $\sqrt{ }$ & $\sqrt{ }$ & $\sqrt{ }$ & $\sqrt{ }$ & \\
\hline Slovenia & $\sqrt{ }$ & $\sqrt{ }$ & $\sqrt{ }$ & $\sqrt{ }$ & $\sqrt{ }$ & $\sqrt{ }$ & $\sqrt{ }$ & $\sqrt{ }$ & $\sqrt{ }$ & $\sqrt{ }$ & $\sqrt{ }$ \\
\hline Spain & $\sqrt{ }$ & $\sqrt{ }$ & $\sqrt{ }$ & $\sqrt{ }$ & $\sqrt{ }$ & $\sqrt{ }$ & $\sqrt{ }$ & $\sqrt{ }$ & $\sqrt{ }$ & $\sqrt{ }$ & $\sqrt{ }$ \\
\hline Sweden & $\sqrt{ }$ & $\sqrt{ }$ & $\sqrt{ }$ & & $\sqrt{ }$ & $\sqrt{ }$ & $\sqrt{ }$ & $\sqrt{ }$ & $\sqrt{ }$ & $\sqrt{ }$ & $\sqrt{ }$ \\
\hline Turkey & & $\sqrt{ }$ & & & $\sqrt{ }$ & $\sqrt{ }$ & & & $\sqrt{ }$ & & \\
\hline
\end{tabular}


Table 3. Individuals with special needs and support provided to their families in Turkey and EU countries [14,18-21]

\begin{tabular}{|c|c|c|c|c|c|c|c|c|c|}
\hline Countries & Counseling & Education & Financial & $\begin{array}{c}\text { Family } \\
\text { Education }\end{array}$ & Health & $\begin{array}{c}\text { Public } \\
\text { Transport } \\
\text { Travelling, } \\
\text { food } \\
\end{array}$ & $\begin{array}{l}\text { Teaching } \\
\text { Material }\end{array}$ & $\begin{array}{c}\text { Subsidised } \\
\text { housing, } \\
\text { fuel, electricity, } \\
\text { telephone }\end{array}$ & $\begin{array}{l}\text { Special Support } \\
\text { (Language, art) }\end{array}$ \\
\hline Austria & $\sqrt{ }$ & $\sqrt{ }$ & $\sqrt{ }$ & $\sqrt{ }$ & $\sqrt{ }$ & $\sqrt{ }$ & $\sqrt{ }$ & $\sqrt{ }$ & $\sqrt{ }$ \\
\hline Belgium & & $\sqrt{ }$ & $\sqrt{ }$ & $\mathrm{v}$ & $\sqrt{ }$ & & $\sqrt{ }$ & & $\sqrt{ }$ \\
\hline Cyprus & $\sqrt{ }$ & $\sqrt{ }$ & $\sqrt{ }$ & $\sqrt{ }$ & $\sqrt{ }$ & $\sqrt{ }$ & $\sqrt{ }$ & & $\sqrt{ }$ \\
\hline Czech Rep. & $\sqrt{ }$ & $\sqrt{ }$ & $\sqrt{ }$ & $\sqrt{ }$ & $\sqrt{ }$ & $\sqrt{ }$ & $\sqrt{ }$ & & $\sqrt{ }$ \\
\hline Denmark & $\sqrt{ }$ & $\sqrt{ }$ & $\sqrt{ }$ & $\sqrt{ }$ & & $\sqrt{ }$ & $\sqrt{ }$ & & \\
\hline Finland & $\sqrt{ }$ & $\sqrt{ }$ & $\sqrt{ }$ & $\sqrt{ }$ & $\sqrt{ }$ & $\sqrt{ }$ & $\sqrt{ }$ & & \\
\hline France & & $\sqrt{ }$ & $\sqrt{ }$ & $\sqrt{ }$ & $\sqrt{ }$ & $\sqrt{ }$ & & & \\
\hline Germany & $\sqrt{ }$ & $\sqrt{ }$ & $\sqrt{ }$ & $\sqrt{ }$ & & & & & $\sqrt{ }$ \\
\hline Greece & $\sqrt{ }$ & $\sqrt{ }$ & $\sqrt{ }$ & $\sqrt{ }$ & $\sqrt{ }$ & $\sqrt{ }$ & $\sqrt{ }$ & & \\
\hline Hungary & $\sqrt{ }$ & $\sqrt{ }$ & $\sqrt{ }$ & $\sqrt{ }$ & $\sqrt{ }$ & $\sqrt{ }$ & $\sqrt{ }$ & & $\sqrt{ }$ \\
\hline Iceland & $\sqrt{ }$ & $\sqrt{ }$ & $\sqrt{ }$ & $\sqrt{ }$ & $\sqrt{ }$ & $\sqrt{ }$ & $\sqrt{ }$ & & $\sqrt{ }$ \\
\hline Ireland & $\sqrt{ }$ & $\sqrt{ }$ & $\sqrt{ }$ & $\sqrt{ }$ & & & $\sqrt{ }$ & & $\sqrt{ }$ \\
\hline Italy & $\sqrt{ }$ & $\sqrt{ }$ & $\sqrt{ }$ & $\sqrt{ }$ & $\sqrt{ }$ & $\sqrt{ }$ & $\sqrt{ }$ & & $\sqrt{ }$ \\
\hline Lithuania & $\sqrt{ }$ & $\sqrt{ }$ & $\sqrt{ }$ & $\sqrt{ }$ & $\sqrt{ }$ & $\sqrt{ }$ & $\sqrt{ }$ & $\sqrt{ }$ & \\
\hline Luxembourg & $\sqrt{ }$ & $\sqrt{ }$ & $\sqrt{ }$ & $\sqrt{ }$ & $\sqrt{ }$ & $\sqrt{ }$ & $\sqrt{ }$ & & $\sqrt{ }$ \\
\hline Malta & $\sqrt{ }$ & $\sqrt{ }$ & $\sqrt{ }$ & $\sqrt{ }$ & & & & & $\sqrt{ }$ \\
\hline Netherland & $\sqrt{ }$ & $\sqrt{ }$ & & $\sqrt{ }$ & & & $\sqrt{ }$ & & $\sqrt{ }$ \\
\hline Norway & $\sqrt{ }$ & $\sqrt{ }$ & $\sqrt{ }$ & $\sqrt{ }$ & $\sqrt{ }$ & & $\sqrt{ }$ & & \\
\hline Poland & & $\sqrt{ }$ & $\sqrt{ }$ & $\sqrt{ }$ & & $\sqrt{ }$ & $\sqrt{ }$ & & \\
\hline Portugal & $\sqrt{ }$ & $\sqrt{ }$ & $\sqrt{ }$ & $\sqrt{ }$ & $\sqrt{ }$ & & $\sqrt{ }$ & & \\
\hline Slovenia & $\sqrt{ }$ & $\sqrt{ }$ & $\sqrt{ }$ & $\sqrt{ }$ & & $\sqrt{ }$ & $\sqrt{ }$ & & $\sqrt{ }$ \\
\hline Spain & $\sqrt{ }$ & $\sqrt{ }$ & $\sqrt{ }$ & $\sqrt{ }$ & $\sqrt{ }$ & & $\sqrt{ }$ & & $\sqrt{ }$ \\
\hline Sweden & $\sqrt{ }$ & $\sqrt{ }$ & $\sqrt{ }$ & $\sqrt{ }$ & & $\sqrt{ }$ & $\sqrt{ }$ & & $\sqrt{ }$ \\
\hline Turkey & $\sqrt{ }$ & $\sqrt{ }$ & $\sqrt{ }$ & $\sqrt{ }$ & $\sqrt{ }$ & $\sqrt{ }$ & & & \\
\hline
\end{tabular}

\section{Conclusions}

In most of the EU member [18-20] states inclusion, integration, and separate education models are applied together for children with special educational requirements who are at the primary school age. Compulsory age to start school in Belgium, Czech Republic, Denmark, Austria, Poland, and Portugal is 6 while it is 4-4,5 in Luxemburg and Southern Cyprus and 5 in the United Kingdom and Hungary. In these countries, individuals with special requirements start school at the same age as their peers. On the other hand, as of the preschool age both the individual himself and his family and classroom teacher receive supporting services. In European Union member states in which compulsory age to start school varies between 4 and 6 , employment of personnel who render services at different levels of education also differs depending on the needs and requirements of the said individuals. 12-year continuing education has been applied to primary, secondary and high school levels with the model of $4+4+4$ in our country. In this application in which the inclusive education is adopted, it is aimed to include the individuals with special needs into the education environments. When the compulsory education periods of the European Union Member States are examined, it can be seen that in Luxembourg, in which the compulsory education starts at the earliest age (Age of 4) among the countries, the two-year preschool education period is included in the compulsory education and free. The compulsory education starts at the age of 5 in Holland, Maltha, and Southern Cyprus while it starts at the age of 7 in France, Sweden, and Lithuania. Another remarkable application is that the compulsory education starts in the preschool period in Greek Cypriot State, Luxembourg, Hungary, Poland and the last two years of preschool education is compulsory in Lithuania and Luxembourg. It is seen that the education practices for the children with special educational needs changed dramatically in European countries recently. It is also seen that the age of the compulsory education is pulled down in the recent years [18-20].

Special education supports in several countries such as Hungary, Lithuania, Luxemburg and Holland cover also the 
migrant and poor children and their families who suffer from social, cultural problems and language-related deprivations [18-20].

However, it should be noted that in our country the level of supporting services rendered is not sufficient due to expert personnel working in the field of special training and education who are insufficient in number. According to the report published by Ministry of National Education, The total number of the students who continue formal education in primary school, secondary school, high school and higher education institutions in the 2014-2015 academic year is 259.282 (male:160.866, female:98416) [24,25].

In countries where concentrated inclusion and integration are applied families are provided with family training, health, financial, and transportation support while classroom teachers are provided with sufficient level of academic knowledge and skills and behavioral management (Czech Republic, Iceland). For children in Turkey who are diagnosed to have special requirements and in need of special training, it is required by laws that these children receive primary school education.

In terms of the legal regulations of the countries, the most notable point is the applications in Italy and Ireland. According to the law which was accepted [14,16-18] as based on the philosophy of forming integrated schools in Italy, the application has been based on inclusive education since 1992. To close the special education school at the level of primary school and the right to be educated with the peers of every child are adapted according to this regulation. The supportive services regarding the needs of the children are provided in the environment the children continue. Another notable application in Ireland is the integrated schools criteria. The suitability of the schools to the integrated schools philosophy and the criteria for this are stated in the report published by National Council for Special Education in 2015 [26,28] for the education of the children with special educational needs. The schools which meet at least 5 or 6 of the following criteria are determined by the ministry and announced on the website with the school with efficient integration certificate: 1) school development plan in terms of leadership and management, 2) mission and vision, supportive service applications determined for the integration philosophy, 3) proof based applications, 4) climate of the school, 5) school life for everybody, 6) preparation and application of the program for integration, 7) application of efficient individualized education programs, 8) learning and teaching strategies, 9) classroom management, 10) supportive services that increase the sustainability of learning and efficient assessment [22,26-28]. The Ministry of National Education $[26,28]$ states that this application is an effective application of the integration philosophy by Ireland around the world and an exemplary education policy.

While the compulsory education period is accepted for the children with special educational needs between the ages of 7-16, the special education support for the preschool period is provided by the municipalities as of the age of 5 . The equal access to education for everyone principle concerns with the quality of the education institutions which provides services in teaching, development, and transition for the children in compulsory education age. Thanks to this application that is based on the assessment of the service qualities of the institutions, the institutions which provide the most qualified services to the children with special educational needs and to their families are determined. This application clearly proves the importance of the supportive services provided to the children with special educational needs in preschool and primary school as well as the importance of the age of starting school [23]. How the children are assessed in preschool education period is seen as important in terms of observing their individual differences and developments in the following years [24].

The evaluation methods concerning observation, development, health and education show similarities in Turkey and EU countries. In addition to informal evaluation techniques such as initial and process evaluation, systematic observation, close monitoring of development, portfolio product evaluation, family and instructor collaboration, assignments and some formal test results in Malta and at least 3 formal evaluation results in Spain are taken into consideration. The 8-year compulsory education system adopted in 1997 in our country was amended to be for 12 years $(4+4+4)$ with the amendment of 2012 by the Ministry of National Education. It is stated that individuals who turned 5 in the academic year 2012-2013 shall start the compulsory education while there are still several problems relating to how students with special requirements who are under inclusion studies will be regulated and arranged and what supporting services will be provided to students and their classroom teachers. Insufficient number of personnel specialized in the field of special training should be corrected through training and employment and on-the-job training for classroom teachers should be addressed.

In conclusion, education and training activities should be based on properties of the said individuals as a whole with relevant personnel, program, and other arrangements. Considering that the training process that starts within the family and that goes on for preschool and primary school ages, quality of these arrangements for students can be expressed as an indicator of social development.

\section{Acknowledgements}

A part of this article was presented as a verbal proceeding at 4th International Conference on New Horizons in Education, 25-27 June Roma, Italy, 2013.

\section{REFERENCES}

[1] B.Sucuoğlu. Efficient Source Applications in the Light of New Primary School Programs and Teacher Sufficiency, 
Ekinoks Publisher, Ankara, 2006.

[2] Online Available: Ministry of National Education, Regulation on Special Education Services, Online available from http://orgm.meb.gov.tr/meb iys dosyalar/2012 10/1011122 6_ozel_egitim_hizmetleri_yonetmeligi_son.pdf

[3] Online Available: The new edition of Diagnostic and Statistical Manual of Mental Disorders (DSM-5) Online available from

https://www.psychiatry.org/psychiatrists/practice/dsm/dsm-5

[4] Online Available: American Psychiatric Association, Diagnostic and Statistical Manual of Mental Disorders (DSM-V) American Online available from APA_DSM-5-Diagnoses-for-Children.pdf

[5] S. Çelenk, N., Tertemiz, N. Kalaycı. Primary School Programs and the Developments, Nobel Publisher, Ankara, 2000.

[6] Online Available: Ministry of National Education, Weekly Course Schedules and Assembly Resolution, Online available from,

http://ttkb.meb.gov.tr/www/ozel-egitim-okullari-ilkokul-ve-o rtaokul-haftalik-ders-cizelgeleri-ve-kurul karari/icerik/84

[7] Online Available: MEB, 12-year Compulsory Education Questions and Answers Online available from, http://www.meb.gov.tr/duyurular/duyurular2012/12Yil_Soru Cevaplar.pdf

[8] Online Available: MEB, Ministry of National Education Regulation on Preschool Education and Primary School Institutions. Online available from,

http://mevzuat.meb.gov.tr/html/ilkveokuloncyon_0/ilkveokul oncyon $0 . h t m l$

[9] S. Eripek. İlköğretim çağı çocuklarının bilişsel, bedensel ve kişilik özellikleri [Cognitive, pyhsical and personality characteristics of primary education children], Online available at

http://w2.anadolu.edu.tr/aos/kitap/IOLTP/1266/unite06.pdf

[10] R.A. Marcon. Positive relationship between parent school involvement and public school inner-city preschoolers' development and academic performance, School Psychology Review, Vol.28, No.3; 395-412,1999.

[11] M. Pretis. Early childhood intervention in Austria: An oerview of 30 years of development and future challenges, International Journal of Early Childhood Special Education(INT-JECSE), Vol.1, No.2; 127-137,2009.

[12] J.L., Epstein, S.B. Sheldon, Moving forward: Ideas for research on school, family, and community partnerships. 7, In C.F. Conrad \& R. Serlin (Eds.) (pp.117-138), SAGE Handbook for research in education: Engaging ideas and enriching inquiry. Sage Publications, Thousand Oaks, CA, 2006.

[13] W.T. Miedel, A. Reynolds. Parent involvement in early intervention for disadvantaged children: Does it matter?, Journal of School Psychology, Vol. 37, No. 4; 379-402, 1999.

[14] Online Available: MEB, Regulation on the Special Education Services, Online available from, http://orgm.meb.gov.tr/meb _iys_dosyalar/2012_10/10111226_ozel_egitim_hizmetleri_y onetmeligi_son.pdf.

[15] E.S. Batu, G. Kurcaali-Iftar. Inclusive Education, Kök Yayınc1lık, Ankara, 2005.
[16] BMBF, Education in Austria 2015/16, Austrian Federal Ministry of Education and Women's Affairs Education. Online available from https://www.bmbf.gv.at/enfr/school/gen_edu/basic.html.

[17] EC (European Commission), Efficiency and Equity in European Education and Training Systems. Online available from Communication from the commission to the Council and to the European Parliament, 8.9.2006, COM (2006), 481 final

[18] Online Available: EC (European Commission), European Agency for Development in Special Needs Education, extracted from Online available from, http://www.european-agency.org Eurydice-Network on Education Systems and Policies in Europe, Online available from

https://webgate.ec.europa.eu/fpfis/mwikis/eurydice/index.ph $\mathrm{p} /$ Countries,

https://webgate.ec.europa.eu/fpfis/mwikis/eurydice/index.ph $\mathrm{p} /$ Topics,

https://webgate.ec.europa.eu/fpfis/mwikis/eurydice/index.ph p/Educational_Support_and_Guidance\#Definition_of_the T arget_Group.28s.29

[19] Online Available: EC (European Commission), Compulsory Education in Europe 2012/2013, Online available from http://eacea.ec.europa.eu/education/eurydice/documents/fact $\mathrm{s}$ and figures/compulsory_education_EN.pd fhttps://webgate.ec.europa.eu/fpfis/mwikis/eurydice/index.p $\mathrm{hp} /$ Publications:Recommended Annual Instruction Time n_Full-time_Compulsory_Education_in_Europe_2015/16

[20] Online Available: EC (European Commission), Special Needs Education Within the Education Systems, Online available from http://www.european-agency.org/country-information

[21] Online Available: EC (European Commission), Special Needs Support in Schools of General Education/Inclusion, Online available from

http://www.european-agency.org/country-information

[22] Online Available: NCSE, Inclusive Education Framework: A Guide for Schools on the Inclusion of Pupils with Special Educational needs, Online available from http://ncse.ie/inclusive-education-framework

[23] G. A., Akcamete, N. Kayhan, M. Sen. Pre-school special education practices in European Union Countries and Turkey, Procedia-Social and Behavioral Sciences, Vol.46, No.1; 1510-1516, 2012.

[24] N. Kayhan, P. Akmese. Examining the preschool educational institutions in European Union Countries and in Turkey. Procedia-Social and Behavioral Sciences, Vol.46; No.1; 1517-1521, 2012.

[25] Online Available: Ministry of National Education, National Education Statistics Formal Education 2014-2015, Online available from ,

http://sgb.meb.gov.tr/www/mill-egitim-istatistikleri-orgun-e gitim-2014-2015/icerik/153 on 05.02.2016

[26] Online Available: Educational Support and Guidance in Ireland Online available from https://webgate.ec.europa.eu/fpfis/mwikis/eurydice/index.ph p/Ireland:Educational_Support_and_Guidance

[27] Online Available: Organisation of Provision to Support 
Inclusive Education Summary Report, Online available from https://www.european-agency.org/sites/default/files/Organis ation $\% 20$ of $\% 20$ Provision $\% 20$ Summary $\% 20$ Report.pdf
[28] Online Available: Procedure for Admission to Primary School 2016 a Guide for Parents November, 2015, Online available from

www.eani.org.uk/_resources/assets/attachment/.../34422.pdf 